\title{
Sensitivity to Copper and Phosphite of Phytophthora Species Associated with Ink Diseases of Chestnut
}

\author{
V. Coelho, S. Coutinho and M.E. Gouveia \\ Instituto Politécnico de Bragança \\ Campus St ${ }^{a}$ Apolónia, Apt 172 \\ 5300-855 Bragança \\ Portugal
}

Keywords: Phytophthora cinnamomi, P. cambivora, ink disease of chestnut

\begin{abstract}
Phytophthora cinnamomi (23 isolates) and $P$. cambivora (3 isolates), isolated from chestnut showing ink disease symptoms or from soil near dead roots of chestnut trees were tested to copper and phosphite sensitivity. Isolates were characterized using an amended agar assay. $\mathbf{E C}_{50}$ values (copper (or phosphite) concentration inhibiting mycelial growth of the pathogen by $50 \%$ ) for each isolate were calculated by plotting probit percentage inhibition against $\log _{10}$ active ingredient (a.i.) concentration. $\mathbf{E C}_{50}$ values of copper ranged from $0.043 \times 10^{-3}$ to $2.025 \times 10^{-3} \mathrm{M}$ in $P$. cinnamomi and $1.970 \times 10^{-3}$ to $4.603 \times 10^{-3} \mathrm{M}$ in $P$. cambivora. $\mathrm{EC}_{50}$ values of phosphite ranged from 2.99 to $172.39 \mu \mathrm{g} \mathrm{ml}^{-1}$ in $P$. cinnamomi and 47.23 to $237.25 \mu \mathrm{g} \mathrm{ml}^{-1}$ in $P$. cambivora. This study may contribute to access the potential utility of these a.i. for managing ink disease of chestnut and to use in the future as benchmark for baseline sensitivity.
\end{abstract}

\section{INTRODUCTION}

Phytophthora cinnamomi and P. cambivora are soil born parasites, both associated with ink disease of chestnut. Chemical control of Phytophthora diseases is a common practice for agricultural crops (Erwin and Ribeiro, 1996; Guest et al., 1995). Copper and fosetil-Al are registered in Portugal for ink disease of chestnut. Resistance of some individuals of the pathogen to the chemicals is of special concern when chemical control is being planned. Some elements such as $\mathrm{Cu}^{2+}$ and $\mathrm{Fe}^{3+}$ were inhibitory to sporangial production and also to mycelial growth of Phytophthora. $\mathrm{Cu}^{2^{+}}$has been shown to be toxic to Phytophthora zoospores at $10^{-7} \mathrm{M}$ and to mycelia at levels of $10^{-2}-10^{-3} \mathrm{M}$ (Halsall, 1977; Smith, 1979). Phosphite, the anionic form of phosphonic acid $\left(\mathrm{HPO}_{3}{ }^{2-}\right)$, which acts directly on the pathogen and indirectly in stimulating a host defence response, controls many plant diseases caused by Phytophthora, even at concentrations in planta that only partially inhibit pathogen growth in vitro (Guest and Bompeix, 1984; Guest and Grant, 1991; Wilkinson et al., 2001).

The purpose of this study was to determine the in vitro sensitivity to copper and phosphite of isolates of Phytophthora species, P. cambivora and P. cinnamomi, associated with ink disease of chestnut.

\section{MATERIAL AND METHODS}

The in vitro sensibility of 26 isolates of Phytophthora (Table 1) to copper concentration $\left(1 \times 10^{-4} \mathrm{M}, 1 \times 10^{-3} \mathrm{M}, 2 \times 10^{-3} \mathrm{M}\right)$ and phosphite concentrations $(5,20$ and 50 $\mu \mathrm{g}$ phosphite $\mathrm{ml}^{-1}$ ) were evaluated by using an amended agar medium. Phytophthora isolates were grown in Petri dishes containing $15 \mathrm{ml}$ of PDA (Potato Dextrose Agar, Difco) with copper addition $\left(\mathrm{CuSO}_{4} \cdot 5 \mathrm{H}_{2} \mathrm{O}\right.$ - Riedel-de-Haën) or with phosphite addition (Phyto-Fos-K, A.M.C., Chemical S. Ltda, Sevilha - 33.7 g/100 ml). Phosphite was sterilized by passing it through a $0.22 \mu \mathrm{m}$ Millipore filter (Millex-HA) and then added to the autoclaved PDA. The Petri plates were incubated in the dark at $24^{\circ} \mathrm{C}$ and mycelial growth was measured 6 days after inoculation. Percentage of inhibition for each isolate at each copper or phosphite concentration was calculated as a percentage of growth in the absence of copper or phosphite. Each experiment contained three replicate plates for each isolate and chemical concentration. The $\mathrm{EC}_{50}$ value for each isolate was calculated by the 
regression line of the probit-transformed percent inhibition plotted against log-transformed fungicide concentration. Data were analysed by General Linear Model (GLM). Independent variables were Phytophthora isolate and phosphite or copper concentration, and the dependent variable was the percentage of growth inhibition on the final day of the experiment.

\section{RESULTS AND DISCUSSION}

Copper concentration had a significant $(\alpha<0.05 \%)$ effect on inhibition of isolates grown on PDA. At low concentrations, mycelium grew normally from the inoculation point, but at higher concentrations mycelial growth was sparse and not uniform.

Growth inhibition becomes greater as copper concentration increases. The effect of the lower concentration of copper $\left(1 \times 10^{-4} \mathrm{M}\right)$ varied between $34.53 \%$ of growth promotion (Pr 120$)$ to $55.02 \%$ of growth inhibition (802) in $P$. cinnamomi isolates. $P$. cambivora isolates when exposed to the same copper concentration, showed $30.43 \%(\mathrm{Pr}$ $135)$ of growth promotion and only $6.01 \%(\mathrm{Ar} 101)$ of growth inhibition. Copper $\mathrm{EC}_{50}$ in $P$. cinnamomi varied between $0.043 \times 10^{-3} \mathrm{M}$ to $2.025 \times 10^{-3} \mathrm{M}$ (isolate 802 and $\operatorname{Pr} 125$ respectively) (Table 1$)$. At the higher copper concentration $\left(2 \times 10^{-3} \mathrm{M}\right)$ studied $34.78 \%$ of $P$. cinnamomi isolates did not grow.

Phytophthora species and isolates within a species vary in their sensitivity to phosphite. Coffey and Bower (1984) obtained $\mathrm{EC}_{50}$ values ranging from 5.2 in $P$. cinnamomi to $224 \mu \mathrm{g} \mathrm{ml}^{-1}$ in $P$. infestans. $P$. cinnamomi was considered to be one of the most sensitive species to phosphite with $\mathrm{EC}_{50}$ ranging from 5.9 to $11.9 \mu \mathrm{g} \mathrm{ml}^{-1}$. Wilkinson et al. (2001) obtained phosphite $\mathrm{EC}_{50}$ values ranging 4 to $148 \mu \mathrm{g} \mathrm{ml}^{-1}$ on 66 P. cinnamomi isolates. The isolates of $P$. cinnamomi tested to phosphite, in this study, could be subjectively assigned to three groups: sensitive isolates were $\mathrm{EC}_{50}<10 \mu \mathrm{g} \mathrm{ml} \mathrm{ml}^{-1}$, intermediate isolates and, tolerant isolates were $\mathrm{EC}_{50}>50 \mu \mathrm{g} \mathrm{ml}^{-1}$. Tolerant isolates ( $\mathrm{Pr}$ 125,805 and R108) are being tested over a large range of phosphite concentrations to determine consistent tolerance and $\mathrm{EC}_{50}$ values. The effect of lower phosphite concentration varied between $5.69 \%(\operatorname{Pr} 125)$ of growth promotion up to $51.65 \%(802)$ of growth inhibition. The most sensitive isolates, at higher phosphite concentration were the isolate 806 and $\operatorname{Pr} 122$ with $76.47 \%$ and $74.05 \%$ of growth inhibition, respectively.

$\mathrm{EC}_{50}$ values of $P$. cambivora were always higher than $P$. cinnamomi for copper and phosphite. Only three $P$. cambivora isolates were obtained in the studied chestnut orchards. The small number of studied isolates of $P$. cambivora did not allow the chemical characterization to be accomplished.

Results from in vitro tests can provide valid measurement for copper compounds which act directly on the pathogen. In vitro tests from phosphite, which has a more complex mode of action, may not provide a realistic and valid measure of tolerance and sensitivity and therefore alternative methods will be necessary to determine the sensitivity or tolerance of the isolates.

\section{Literature Cited}

Coffey, M.D. and Bower, L.A. 1984. In vitro variability among isolates of eight Phytophthora species in response to phosphorus acid. Phytopathology 74:738-42.

Erwin, D.C. and Ribeiro, O.K. 1996. Phytophthora Diseases Worldwide. APS Press, St. Paul, Minnesota.

Guest, D.I., Pegg, K.C. and Whiley, A.W. 1995. Control of Phytophthora diseases of tree crops using trunk-injected phosphonates. Hort. Rev. 17:299-330.

Guest, D.I. and Bompeix, G. 1984. Fosetil-Al as a tool in understanding the resistant response in plants. Phytophthora Newsletter 12:62-69.

Guest, D.I. and Grant, B.R. 1991. The complex action of phosphonates as antifungal agents. Biol. Rev. 66:159-87.

Halsall, D.M. 1977. Effects of certain cations on the formation and infectivity of Phytophthora zoospores. 2. Effects of copper, boron, cobalt, manganese, molybdenum and zinc ions. Can. J. Microbiol. 23:1002-10. 
Smith, P.M. 1979. A study of the effects of fungitoxic compounds on Phytophthora cinnamomi in water. Ann. Appl. Biol. 93:149-57.

Wilkinson, C.J., Holmes, J.M., Dell, B., Tynan, K.M., McComb, J.A., Shearer, B., Colquhoum, I.J. and Hardy, G.E.J. 2001. Effect of phosphite on in planta zoospore production of Phytophthora cinnamomi. Plant Pathol. 50:587-593.

\section{Tables}

Table 1. Isolates of Phytophthora species tested for sensitivity to copper and phosphite, and $\mathrm{EC}_{50}$ values for Phytophthora isolates.

\begin{tabular}{|c|c|c|c|c|c|}
\hline Isolate & Isolated from & Location & Specie & $\begin{array}{c}\text { Ec }_{50} \text { Phosphite } \\
\left(\mu \mathrm{g} \mathrm{ml}^{-1}\right)\end{array}$ & $\begin{array}{c}\mathrm{Ec}_{50} \text { Copper } \\
(\mathrm{M})\end{array}$ \\
\hline $\operatorname{Pr} 112$ & Young chestnut tree & Paredes & P. cinnamomi & 9.20 & $0.569 \times 10^{-3}$ \\
\hline $\operatorname{Pr} 115$ & Young chestnut tree & Paredes & P. cinnamomi & 16.83 & $1.358 \times 10^{-3}$ \\
\hline $\operatorname{Pr} 120$ & Young chestnut tree & Paredes & P. cinnamomi & 23.93 & $1.538 \times 10^{-3}$ \\
\hline Pr 122 & Soil & Paredes & P. cinnamomi & 8.09 & $0.561 \times 10^{-3}$ \\
\hline $\operatorname{Pr} 123$ & Soil & Paredes & P. cinnamomi & 7.34 & $1.471 \times 10^{-3}$ \\
\hline $\operatorname{Pr} 124$ & Soil & Paredes & P. cinnamomi & 19.53 & $0.808 \times 10^{-3}$ \\
\hline $\operatorname{Pr} 125$ & Soil & Paredes & P. cinnamomi & 106.68 & $2.025 \times 10^{-3}$ \\
\hline $\operatorname{Pr} 128$ & Soil & Paredes & P. cinnamomi & 16.10 & $0.678 \times 10^{-3}$ \\
\hline Pr 129 & Soil & Paredes & P. cinnamomi & 13.06 & $1.291 \times 10^{-3}$ \\
\hline $\operatorname{Pr} 130$ & Soil & Paredes & P. cinnamomi & 13.18 & $0.446 \times 10^{-3}$ \\
\hline $\operatorname{Pr} 135$ & Soil & Paredes & P. cambivora & 47.23 & $1.970 \times 10^{-3}$ \\
\hline 801 & Young chestnut tree & Rossas & P. cinnamomi & - & $0.220 \times 10^{-3}$ \\
\hline 802 & Young chestnut tree & Rossas & P. cinnamomi & 2.99 & $0.043 \times 10^{-3}$ \\
\hline 803 & Young chestnut tree & Rossas & P. cinnamomi & 27.42 & $0.139 \times 10^{-3}$ \\
\hline 804 & Young chestnut tree & Rossas & P. cinnamomi & 31.80 & $0.174 \times 10^{-3}$ \\
\hline 805 & Young chestnut tree & Rossas & P. cinnamomi & 83.35 & $0.085 \times 10^{-3}$ \\
\hline 806 & Young chestnut tree & Rossas & P. cinnamomi & 11.86 & $0.429 \times 10^{-3}$ \\
\hline 807 & Young chestnut tree & Rossas & P. cinnamomi & - & $0.447 \times 10^{-3}$ \\
\hline 808 & Young chestnut tree & Rossas & P. cinnamomi & 26.85 & $0.216 \times 10^{-3}$ \\
\hline 809 & Young chestnut tree & Rossas & P. cinnamomi & 27.51 & $0.446 \times 10^{-3}$ \\
\hline 810 & Young chestnut tree & Rossas & P. cinnamomi & 33.49 & $0.106 \times 10^{-3}$ \\
\hline R 105 & Young chestnut tree & Rossas & P. cinnamomi & 34.32 & $0.116 \times 10^{-3}$ \\
\hline R106 & Young chestnut tree & Rossas & P. cinnamomi & 9.54 & $0.211 \times 10^{-3}$ \\
\hline R108 & Young chestnut tree & Rossas & P. cinnamomi & 172.39 & - \\
\hline Ar 101 & Old chestnut tree & Arufe & P. cambivora & 237.25 & - \\
\hline Ar 104 & Old chestnut tree & Arufe & P. cambivora & - & $4.603 \times 10^{-3}$ \\
\hline
\end{tabular}

- not calculated 
